\title{
Utility of serum procalcitonin values in patients with acute exacerbations of chronic obstructive pulmonary disease: a cautionary note
}

This article was published in the following Dove Press journal:

International Journal of COPD

22 February 2012

Number of times this article has been viewed

\author{
Ann R Falsey ${ }^{1,2}$ \\ Kenneth L Becker ${ }^{3}$ \\ Andrew J Swinburne ${ }^{2}$ \\ Eric S Nylen ${ }^{3}$ \\ Richard H Snider ${ }^{3}$ \\ Maria A Formica ${ }^{2}$ \\ Patricia A Hennessey ${ }^{2}$ \\ Mary M Criddle ${ }^{2}$ \\ Derick R Peterson ${ }^{4}$ \\ Edward E Walsh ${ }^{1,2}$ \\ 'Department of Medicine, University \\ of Rochester, ${ }^{2}$ Rochester General \\ Hospital, Rochester, NY, ${ }^{3}$ Veterans \\ Affairs Medical Center and George \\ Washington University, Washington \\ DC, ${ }^{4}$ Biostatistics and Computational \\ Biology, University of Rochester, \\ Rochester, NY, USA
}

Background: Serum procalcitonin levels have been used as a biomarker of invasive bacterial infection and recently have been advocated to guide antibiotic therapy in patients with chronic obstructive pulmonary disease (COPD). However, rigorous studies correlating procalcitonin levels with microbiologic data are lacking. Acute exacerbations of COPD (AECOPD) have been linked to viral and bacterial infection as well as noninfectious causes. Therefore, we evaluated procalcitonin as a predictor of viral versus bacterial infection in patients hospitalized with AECOPD with and without evidence of pneumonia.

Methods: Adults hospitalized during the winter with symptoms consistent with AECOPD underwent extensive testing for viral, bacterial, and atypical pathogens. Serum procalcitonin levels were measured on day 1 (admission), day 2, and at one month. Clinical and laboratory features of subjects with viral and bacterial diagnoses were compared.

Results: In total, 224 subjects with COPD were admitted for 240 respiratory illnesses. Of these, 56 had pneumonia and 184 had AECOPD alone. A microbiologic diagnosis was made in 76 (56\%) of 134 illnesses with reliable bacteriology (26 viral infection, 29 bacterial infection, and 21 mixed viral bacterial infection). Mean procalcitonin levels were significantly higher in patients with pneumonia compared with AECOPD. However, discrimination between viral and bacterial infection using a $0.25 \mathrm{ng} / \mathrm{mL}$ threshold for bacterial infection in patients with AECOPD was poor.

Conclusion: Procalcitonin is useful in COPD patients for alerting clinicians to invasive bacterial infections such as pneumonia but it does not distinguish bacterial from viral and noninfectious causes of AECOPD

Keywords: virus, bacterial infection, procalcitonin, chronic obstructive pulmonary disease, bronchitis

\section{Introduction}

Guidelines from the Global Initiative for Chronic Obstructive Pulmonary Disease (GOLD) recommend antibiotics for the treatment of moderate to severe acute exacerbations of chronic obstructive pulmonary disease (AECOPD). ${ }^{1}$ Several meta-analyses support these recommendations to reduce mortality and treatment failures. ${ }^{2}$ Although purulent sputum and growth of a bacterial pathogen suggest infection, definitive causality with an AECOPD is difficult because patients may be chronically colonized. ${ }^{3,4}$ In addition, recent studies using molecular diagnostics indicate that a substantial proportion of AECOPD are associated with viral infection. ${ }^{5,6}$ Accurate methods to differentiate viral and bacterial respiratory infections to allow targeted antibiotic therapy would be beneficial. Measurement of serum procalcitonin has been proposed to discriminate bacterial infection from viral or noninfectious causes.?
Correspondence: Ann R Falsey Infectious Disease Unit, Rochester General Hospital, I 425 Portland Avenue, Rochester, NY 1462I, USA

Tel +l 5859224339

Fax + I 5859225168

Email ann.falsey@rochestergeneral.org 
Procalcitonin is a calcitonin precursor that is normally produced in neuroendocrine cells of the thyroid and lungs. However, in response to bacterial infections, procalcitonin is produced by cells throughout the body. ${ }^{8,9}$ Stimuli of procalcitonin include bacterial products, including endotoxin and proinflammatory cytokines such as tumor necrosis factor alpha, whereas procalcitonin is attenuated by viralinduced interferon- $\gamma{ }^{8,10}$ Procalcitonin testing has been used successfully as a guide to predict serious bacterial infections and medical outcomes in patients with sepsis. ${ }^{11,12}$ Recently, procalcitonin has been assessed as a guide to antibiotic therapy in patients with respiratory illnesses, including COPD. ${ }^{7,13-18}$ However, microbiologic assessment to prove the presence or absence of bacterial infection was not performed in the majority of subjects in most trials, which is a concern for the Food and Drug Administration and Infectious Disease Society of America, as noted in a recent workshop. ${ }^{19}$ Therefore, we examined the utility of serum procalcitonin levels as predictors of viral and bacterial infection in patients hospitalized with AECOPD using rigorous viral and bacteriologic studies.

\section{Methods}

\section{Patient population}

The study was performed at Rochester General Hospital, a 520-bed general medical-surgical hospital located in Rochester (Monroe County), NY. Subjects were participating in a larger ongoing study of the relationship between procalcitonin level and definitive bacterial and viral diagnosis (to be described in a separate publication). Adults $\geq 21$ years of age admitted through the Emergency Department to Rochester General Hospital with an admitting diagnosis compatible with acute respiratory tract infection were recruited from November 1 to May 30 during 2008-2009 and 2009-2010. A subset of subjects with a past medical history of COPD and smoking and symptoms consistent with AECOPD according to the GOLD criteria (increased dyspnea, cough, and/or increased sputum volume or purulence) were identified for the present analysis. Confirmation of COPD was sought as available in the hospital medical records. Patients were screened within 24 hours of admission and those given antibiotics prior to admission, or who had immunosuppression, cavitating lung disease, or witnessed aspiration were excluded. ${ }^{20}$ In addition, subjects with other conditions known to increase serum procalcitonin levels (burns, trauma, pancreatitis, renal failure, thyroid tumors) were excluded from the study. Subjects or legal guardians provided written informed consent. The study was approved by the University of Rochester and Rochester General Hospital institutional review boards.

\section{Illness evaluation}

At enrollment, demographic, clinical, and laboratory information was collected. Chest radiographs were classified by a pulmonary specialist as infiltrate or no infiltrate. Testing for bacterial pathogens included: blood cultures, sputum culture, and Gram stain; nose and throat swabs for Mycoplasma pneumoniae and Chlamydophila pneumoniae polymerase chain reaction; and urine for Streptococcus pneumoniae antigen and pneumococcal serology. Sputum was induced with normal saline if subjects were unable to expectorate an adequate sputum sample spontaneously. Specimens were considered adequate by standard criteria of $>25$ polymorphonuclear leukocytes and $<10$ epithelial cells per high power field. Nose and throat swabs and sputum were tested for viruses by reverse transcriptase polymerase chain reaction. Sera were collected on hospital day 1 (prior to antibiotics) and 4-6 weeks later for viral serology, pneumococcal serology, and procalcitonin measurements. Serum was also collected on hospital days 2 and 28 for procalcitonin measurement.

\section{Laboratory methods}

Standard microbiological testing including blood cultures, sputum Gram stain and culture, influenza antigen testing, and viral cultures were performed by the Rochester General Hospital clinical laboratory. Sputum samples were plated on blood, chocolate, and MacConkey agar. Legionella testing was performed at the discretion of the treating physician. Pneumococcal surface protein A antigens covering families 1 and 2, obtained from the University of Alabama Bacterial Respiratory Pathogen Reference Laboratory, were used in an enzyme immunoassay. ${ }^{21} \mathrm{~A} \geq 4$-fold rise in titer was considered evidence of infection. Urine samples were assayed for pneumococcal antigen using BinaxNOW ${ }^{\circledR}$ (Binax Inc, Scarborough, ME) urine assay.22

\section{Procalcitonin}

Procalcitonin was measured by resolved amplified cryptate emission technology (Kryptor PCT, Brahms, Henningsdorf, Germany). Functional sensitivity is $0.06 \mathrm{ng} / \mathrm{mL}$ (normal $0.033 \pm 0.003 \mathrm{ng} / \mathrm{mL}){ }^{12,23,24}$ Immunoglobulin $\mathrm{G}$ titers in acute and convalescent serum for each virus was determined using established EIA methods. ${ }^{25} \mathrm{~A} \geq 4$-fold rise in viral specific immunoglobulin $\mathrm{G}$ was considered evidence of infection. 


\section{Real-time polymerase chain reaction}

Assays for respiratory syncytial virus, human metapneumovirus, M. pneumoniae, and C. pneumoniae used published methods. ${ }^{25-27}$ Primers and probes for other viruses were as follows: influenza A (matrix gene), influenza B (nonstructural 1 [NS1] gene), coronaviruses (polymerase gene), and parainfluenza viruses (nucleocapsid gene). Sequences can be supplied on request. Bacteriology was considered unreliable if sputum was not obtained or was obtained after 6 hours of antibiotics, or was of inadequate quality. Subjects were not considered to be viral infection alone or no infectious diagnosis unless "reliable" bacteriology was negative.

\section{Statistical analysis}

Fisher's Exact and $t$-tests were used to compare distributions of categorical and continuous clinical variables for pneumonia versus AECOPD patients. Differences in procalcitonin levels were evaluated using the Wilcoxon test, summarized using both means and standard deviations and medians with interquartile range, and receiver operator curves were plotted and area under the curve tabulated. Multiple logistic regression was used to model maximum (procalcitonin over days $1-2$ ) $\geq 0.25$ as a function of clinical covariates. SAS 9.2 was used for all analyses, with tests performed at the two-sided 0.05 level.

\section{Results}

\section{Enrollment and microbiology}

During two winters from 2008 to 2010, we enrolled 532 subjects, of whom 224 had a history of COPD and a respiratory illness with symptoms of AECOPD. Of these 224 subjects, 213 had a single illness, 12 had two, and one subject had three hospitalizations for a total of 240 illnesses evaluated. The average time between AECOPD admissions for subjects with more than one illness evaluation was $7 \pm 4$ months. A diagnosis of COPD was confirmed by pulmonary function testing, pulmonary physician evaluation, or radiographic changes in $90 \%$ of subjects. Chest radiographs on admission revealed pneumonia in 56 cases, and 184 illnesses were considered to be AECOPD alone (Figure 1). Bacteriology was considered reliable in $134(56 \%)$ of the 240 illnesses (104 AECOPD and 30 pneumonia). Notably, 47 viral infections alone (37 AECOPD and 10 pneumonia) were excluded from further analyses of microbiology, primarily because sputum samples were collected more than 6 hours after antibiotics had been started. No patient was bacteremic. A variety of viral pathogens were identified and $45 \%$ were associated with bacterial infection (Table 1). S. pneumoniae (22 cases) was the most common bacterial organism identified and was associated with viral infection in $13(59 \%)$ and mixed bacterial infection in three (14\%). Of the 22 subjects with pneumococcal infection, half had more than one positive test (ie, sputum culture, pneumococcal serology, or urine antigen). Of the 31 subjects considered to have bacterial infection based on sputum culture alone, all had 3-4+ growth of a potential pathogen and $87 \%$ had a consistent Gram stain.

\section{Pneumonia procalcitonin analysis}

Procalcitonin values were measured on day 1 (admission), day 2 , and at one month convalescence. Mean procalcitonin

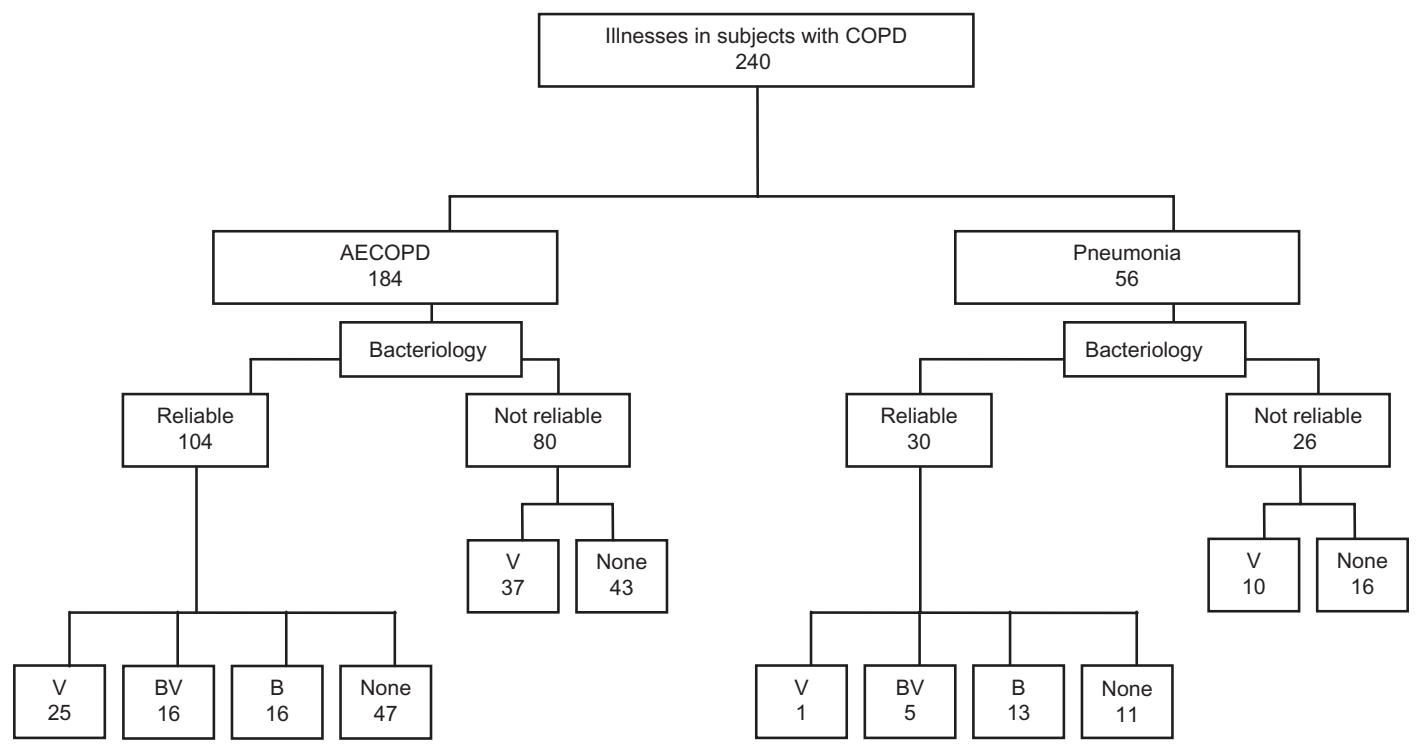

Figure I Flow chart of patient groups. Bacteriology is divided into reliable and not reliable.

Abbreviations: $\mathrm{V}$, viral alone; B, bacterial alone; BV, bacterial + viral; none, no microbiologic diagnosis; COPD, chronic obstructive pulmonary disease. 
Table I Microbiology in subjects with reliable bacteriology

\begin{tabular}{lll}
\hline Organism & $\begin{array}{l}\text { AECOPD } \\
\mathbf{n}=\mathbf{1 0 4}\end{array}$ & $\begin{array}{l}\text { Pneumonia } \\
\mathbf{n}=\mathbf{3 0}\end{array}$ \\
\hline Single organism infections & & \\
Influenza A & 5 & 0 \\
Influenza B & 0 & 0 \\
Respiratory syncytial virus & 7 & 0 \\
Human metapneumovirus & $\mathrm{I}$ & 0 \\
Parainfluenza viruses (I-3) & 3 & 0 \\
Coronaviruses (229E and OC43) & 8 & $\mathrm{I}$ \\
Streptococcus pneumoniae & 2 & 4 \\
Haemophilus influenzae & 4 & $\mathrm{I}$ \\
Moraxella catarrhalis & $\mathrm{I}$ & $\mathrm{I}$ \\
Staphylococcus aureus & $\mathrm{I}$ & 3 \\
Gram-negative rods & 4 & 2 \\
Mycoplasma pneumoniae & 0 & 2 \\
Chlamydophila pneumoniae & 0 & 0 \\
Multiple pathogen infections & & \\
Mixed viral & $\mathrm{I}$ & 0 \\
Viral + S. pneumoniae & 9 & 3 \\
Viral + other bacteria & 7 & 2 \\
S. pneumoniae + other bacteria & 4 & 0 \\
Mixed other bacteria & 0 &
\end{tabular}

Abbreviation: AECOPD, acute exacerbations of chronic obstructive pulmonary disease.

values were higher in COPD patients with pneumonia compared with those with AECOPD only (Table 2). Procalcitonin values decreased significantly in both groups at the convalescent time point. Using published procalcitonin thresholds of $\geq 0.25 \mathrm{ng} / \mathrm{mL}$ as indicative of possible, and $\geq 0.5 \mathrm{ng} / \mathrm{mL}$ as probable bacterial infection, $59 \%$ of pneumonia patients would have been classified as possible and $48 \%$ as probable bacterial infection using the maximum procalcitonin on either the day 1 or day 2 measurement. ${ }^{15,16}$

\section{AECOPD procalcitonin analysis}

Clinical features

Because empiric antibiotics are recommended for all patients with pneumonia, further analyses were restricted to those with AECOPD only. In contrast with subjects with radiographic evidence of pneumonia, only 31 of $184(17 \%)$ in the AECOPD group had procalcitonin values $\geq 0.25 \mathrm{ng} / \mathrm{mL}$. Clinical features associated with a procalcitonin value $<$ or $\geq 0.25 \mathrm{ng} / \mathrm{mL}$ in the AECOPD group are shown in Table 3. Patients with elevated procalcitonin values more often received inhaled or oral steroids, had higher white blood cell levels, temperature, intensive care unit admission rates, and CURB-65 scores. Of note, the frequency of subjects having the three cardinal symptoms warranting antibiotics, as defined by Anthonisen criteria (increased dyspnea, sputum volume, sputum purulence), were similar in the two groups, as were the rates of documented bacterial infections. Clinical features were evaluated by logistic regression [odds ratio (OR), 95\% confidence interval (CI)] and elevated white blood cells (OR 1.2 [95\% CI 1.1-1.3], $P=0.0004$ ), temperature (OR 1.9 [95\% CI 1.2-3.0], $P=0.01$ ). and ICU admission (OR $3.9[95 \% \mathrm{CI}$ 1.3-3.0], $P=0.01$ ) remained significant associations.

\section{Microbiology}

Clinical features were not significantly different for AECOPD due to viral infection alone compared with those with bacterial infection alone or mixed viral bacterial infection with the exception of greater inhaled corticosteroid use in the bacterial infection alone + mixed viral bacterial infection group (data not shown). Maximum procalcitonin values on day 1 or 2 in patients with bacterial infection (bacterial infection

Table 2 Procalcitonin values $(\mathrm{ng} / \mathrm{mL}$ ) of subjects with pneumonia compared with those with acute exacerbations of chronic obstructive pulmonary disease

\begin{tabular}{|c|c|c|c|c|}
\hline \multirow[t]{2}{*}{ Study group and day } & \multirow{2}{*}{$\begin{array}{l}\text { Mean } \pm \text { SD } \\
\text { ProCT ng/mL }\end{array}$} & Median (IQR) & \multirow[t]{2}{*}{ Wilcoxon exact test } & \multirow[t]{2}{*}{$\operatorname{AUC}(95 \% \mathrm{Cl})$} \\
\hline & & ProCT ng/mL & & \\
\hline \multicolumn{5}{|l|}{ Hospital day I (admission) } \\
\hline Pneumonia $(n=56)$ & $3.62 \pm 17.38$ & $0.31(1.29)$ & $P<0.0001$ & $0.76(0.68-0.84)$ \\
\hline $\operatorname{AECOPD}(n=|8|)$ & $0.39 \pm 2.22$ & $0.08(0.07)$ & & \\
\hline \multicolumn{5}{|l|}{ Hospital day 2} \\
\hline Pneumonia $(n=54)$ & $3.30 \pm 10.32$ & $0.33(0.69)$ & $P<0.0001$ & $0.75(0.67-0.82)$ \\
\hline $\operatorname{AECOPD}(n=172)$ & $0.49 \pm 2.26$ & $0.09(0.09)$ & & \\
\hline \multicolumn{5}{|l|}{ Maximum on day 1 or 2} \\
\hline Pneumonia $(n=56)$ & $4.73 \pm 17.92$ & $0.39(2.33)$ & $P<0.0001$ & $0.75(0.67-0.83)$ \\
\hline $\operatorname{AECOPD}(n=184)$ & $0.52 \pm 2.31$ & $0.09(0.01)$ & & \\
\hline \multicolumn{5}{|l|}{ Days $28-42$} \\
\hline Pneumonia $(n=46)$ & $0.22 \pm 0.47$ & $0.07(0.09)$ & $P=0.22$ & $0.56(0.46-0.66)$ \\
\hline $\operatorname{AECOPD}(n=153)$ & $0.12 \pm 0.33$ & $0.06(0.06)$ & & \\
\hline
\end{tabular}

Abbreviations: AECOPD, acute exacerbations of chronic obstructive pulmonary disease; AUC, area under the concentration-time curve; $\mathrm{Cl}$, confidence interval; IQR, interquartile range; ProCT, procalcitonin. 
Table 3 Clinical characteristics of subjects with nonpneumonic acute exacerbations of chronic obstructive pulmonary disease stratified by procalcitonin values above and below $0.25 \mathrm{ng} / \mathrm{mL}$

\begin{tabular}{|c|c|c|c|}
\hline & $\begin{array}{l}\text { ProCT }<0.25 \mathrm{ng} / \mathrm{mL} \\
\mathrm{n}=\mathrm{I} 53\end{array}$ & $\begin{array}{l}\text { ProCT } \geq 0.25 \mathrm{ng} / \mathrm{mL} \\
\mathrm{n}=3 \mathrm{I}\end{array}$ & $P$ value \\
\hline Age (mean \pm SD) & $66.3 \pm 12.3$ & $68.8 \pm 14.2$ & 0.31 \\
\hline Male (\%) & $83(54)$ & $14(45)$ & 0.43 \\
\hline Race, white & $|3|(86)$ & $29(90)$ & 0.58 \\
\hline Diabetes & $52(34)$ & II (35) & 1.0 \\
\hline Congestive heart failure & $47(3 \mathrm{I})$ & $13(42)$ & 0.29 \\
\hline Influenza vaccine & $108(7 I)$ & $24(74)$ & 0.52 \\
\hline Pneumococcal vaccine & 144 (94) & $30(97)$ & 1.0 \\
\hline Chronic oral steroid use & $25(16)$ & II (35) & 0.02 \\
\hline Chronic inhaled steroid use & $83(54)$ & $24(77)$ & 0.02 \\
\hline Home oxygen use & $63(4 I)$ & $17(55)$ & 0.17 \\
\hline \multicolumn{4}{|l|}{ Symptoms (\%) } \\
\hline Upper respiratory tract infection & $116(76)$ & $20(65)$ & 0.26 \\
\hline Cough & 144 (94) & $29(94)$ & 0.44 \\
\hline Sputum production* & $120(78)$ & $26(84)$ & 0.62 \\
\hline Purulent sputum* & $91(59)$ & $18(58)$ & 1.0 \\
\hline Dyspnea* & 148 (97) & $30(97)$ & 1.0 \\
\hline Three Anthonisen criteria present & $87(57)$ & $17(55)$ & 0.85 \\
\hline Rigors & $35(23)$ & $6(19)$ & 0.48 \\
\hline \multicolumn{4}{|l|}{ Physical examination (\%) } \\
\hline Wheezing & $123(80)$ & $23(74)$ & 0.48 \\
\hline Rales & $36(24)$ & II (35) & 0.18 \\
\hline Rhonchi & $43(28)$ & $8(26)$ & 1.0 \\
\hline Diaphoresis & $14(9)$ & $7(23)$ & 0.06 \\
\hline Temperature (mean $\pm S D)$ & $36.9 \pm 0.7$ & $37.3 \pm 1.2$ & 0.01 \\
\hline Respiratory rate (mean $\pm \mathrm{SD}$ ) & $26 \pm 6$ & $27 \pm 10$ & 0.17 \\
\hline Oxygen saturation (mean $\pm \mathrm{SD}$ ) & $91.7 \pm 6$ & $92.8 \pm 5.1$ & 0.31 \\
\hline White blood cells $\times 10^{3} / \mathrm{mL}($ mean $\pm S D)$ & $10.4 \pm 3.9$ & $14.2 \pm 6.4$ & 0.0001 \\
\hline$\%$ neutrophils (mean \pm SD) & $72 \pm 13$ & $75 \pm 16$ & 0.16 \\
\hline$\%$ band forms (mean $\pm S D)$ & $1.5 \pm 2.4$ & $2.8 \pm 3.7$ & 0.01 \\
\hline CURB-65 score & $1.6 \pm 1.0$ & $2.3 \pm 1.0$ & 0.0002 \\
\hline Bacterial infection documented & $24(16)$ & $8(26)$ & 0.20 \\
\hline Intensive care & $12(8)$ & $8(26)$ & 0.008 \\
\hline Length of stay & $7 \pm 32$ & $8 \pm 9$ & 0.93 \\
\hline Death & $3(2)$ & I (3) & 0.52 \\
\hline
\end{tabular}

Note: *Anthonisen criteria.

Abbreviations: SD, standard deviation; ProCT, procalcitonin.

alone + mixed viral bacterial infection) were compared with those without bacterial infection (viral infection alone + no pathogen identified) and were not significantly different (Table 4, analysis A). Because procalcitonin is thought to be attenuated by virally induced interferon, procalcitonin values were compared for those having bacterial infection alone with those having both bacterial and viral infection (Table 4, analysis B). Procalcitonin values were slightly higher in the mixed viral bacterial infection group compared with the bacterial infection alone group, indicating that the presence of concomitant viral infection does not significantly attenuate the procalcitonin response in patients with dual infections. Furthermore, among patients with known viral infection (viral infection alone or mixed viral bacterial infection, Table 4, analysis C), procalcitonin values were significantly higher in the mixed viral bacterial infection group. Given the lack of difference noted in analysis A, this finding might suggest that the presence of a viral infection is necessary for invasive bacterial infection. Using the $\geq 0.25 \mathrm{ng} / \mathrm{mL}$ threshold, the specificity for bacterial infection among patients with a documented viral infection was $96 \%$ but sensitivity was low at $31 \%$, with a positive predictive value of $83 \%$ and negative predictive value of $69 \%$ (Figure 2). Although a significant difference in the mean and median procalcitonin values in this group could be demonstrated, discrimination between viral and bacterial coinfection by procalcitonin was poor (Figure 3 ). Although only one of 25 patients with virus infection alone would have been misclassified as possible bacterial infection, 
Table 4 Maximum day I or 2 serum ProCT values in subjects with acute exacerbations of chronic obstructive pulmonary disease and reliable bacteriology

\begin{tabular}{|c|c|c|c|c|c|}
\hline Analysis & Groups & $\begin{array}{l}\text { Mean } \pm \text { SD } \\
\text { ProCT ng/mL }\end{array}$ & $\begin{array}{l}\text { Median (IQR) } \\
\text { ProCT ng/mL }\end{array}$ & $\begin{array}{l}\text { Wilcoxon exact } \\
\text { test }\end{array}$ & $\operatorname{AUC}(95 \% \mathrm{Cl})$ \\
\hline \multirow[t]{2}{*}{ A } & $\begin{array}{l}\text { Any bacterial } \\
\mathrm{n}=32\end{array}$ & $0.32 \pm 0.57$ & $0.10(0.17)$ & $P=0.06$ & $0.62(0.49-0.74)$ \\
\hline & $\begin{array}{l}\text { Nonbacterial } \\
n=72\end{array}$ & $0.20 \pm 0.66$ & $0.08(0.06)$ & & \\
\hline \multirow[t]{2}{*}{ B } & $\begin{array}{l}\text { Bacterial alone } \\
n=16\end{array}$ & $0.17 \pm 0.21$ & $0.09(0.09)$ & $P=0.06$ & $0.70(0.5 I-0.88)$ \\
\hline & $\begin{array}{l}\text { Bacterial + virus } \\
\mathrm{n}=16\end{array}$ & $0.46 \pm 0.76$ & $0.14(0.25)$ & & \\
\hline \multirow[t]{2}{*}{ C } & $\begin{array}{l}\text { Bacterial + virus } \\
\mathrm{n}=16\end{array}$ & $0.46 \pm 0.76$ & $0.14(0.25)$ & $P=0.03$ & $0.70(0.53-0.87)$ \\
\hline & $\begin{array}{l}\text { Virus alone } \\
\mathrm{n}=25\end{array}$ & $0.11 \pm 0.07$ & $0.09(0.07)$ & & \\
\hline
\end{tabular}

Abbreviations: $\mathrm{AUC}$, area under the concentration-time curve; $\mathrm{Cl}$, confidence interval; IQR, interquartile range; ProCT, procalcitonin.

11 of 16 patients (69\%) with concomitant bacterial infection would have been categorized as low risk of bacterial infection. Interestingly, the single patient with a viral infection alone and elevated procalcitonin levels had influenza complicated by pericardial tamponade, necessitating surgical intervention on the second hospital day. As demonstrated in Figure 3, most subjects in any category (viral alone, viral + bacterial, or bacterial alone) fell below the $0.25 \mathrm{ng} / \mathrm{mL}$ threshold on day 1 or 2 of hospitalization.

\section{Discussion}

Infection is a major cause of morbidity and mortality among patients with COPD. ${ }^{28}$ In COPD patients presenting to the

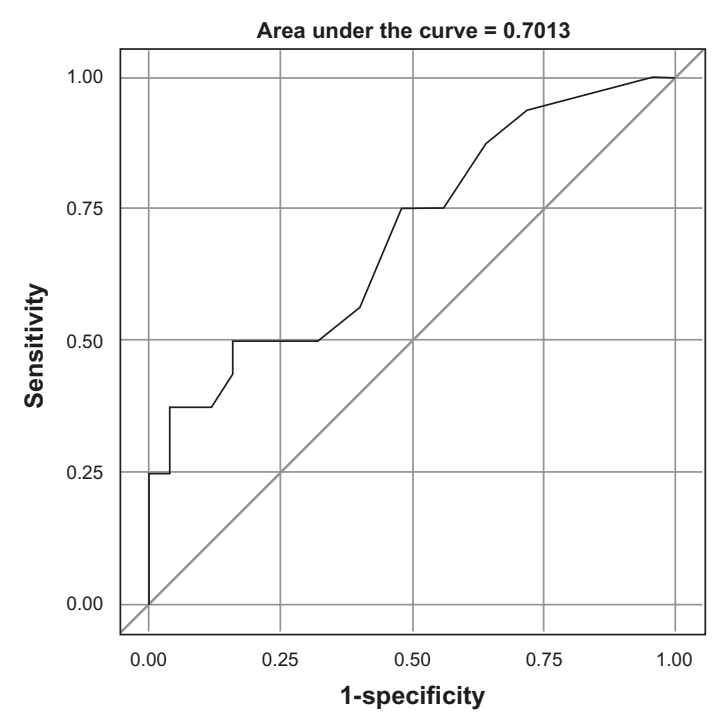

Figure 2 Receiver operator curve for procalcitonin as a diagnostic tool for bacterial infection in patients with a documented viral infection and acute exacerbations of chronic obstructive pulmonary disease without pneumonia. Specificity is indicated on $y$-axis and sensitivity on $x$-axis. hospital with dyspnea, our study demonstrates a wide variety of viral and bacterial pathogens, as well as a high incidence of pneumonia. Recently, use of procalcitonin to guide clinical decisions has been shown to reduce antibiotic use significantly in patients with respiratory illnesses without compromising composite patient outcomes in a number of randomized interventional trials. ${ }^{13-18,29}$ Although procalcitonin-guided decisions have been promulgated as a method to "rule out" bacterial infection, the $0.25 \mathrm{ng} / \mathrm{mL}$ threshold for recommending antibiotic treatment is not based on microbiologic data. Recovery without antibiotics or with an abbreviated course has been equated with the absence of a bacterial infection. The lack of microbiologic correlation with procalcitonin levels is likely to slow endorsement of procalcitonin-guided management in respiratory illness. . $^{19,30,31}$

Ours is the first study in the US to examine the utility of procalcitonin levels in patients with COPD, and consistent with the European literature, we found that a high procalcitonin level was relatively specific for invasive bacterial disease such as pneumonia. ${ }^{32,33}$ In addition, elevated procalcitonin values in the AECOPD group correlated with higher temperature, white blood cells, and more severe illness, suggesting the possibility of occult pneumonia. Thus, high procalcitonin values may alert clinicians to the presence of bacterial pneumonia when the chest radiograph results are negative or ambiguous.

However, our results also indicate that minor elevations at the low end of the procalcitonin spectrum do not correlate with bacterial infection for subjects with AECOPD alone. It has been estimated that approximately $40 \%-50 \%$ of AECOPD cases are due to bacterial infections. ${ }^{34}$ The precise contribution of bacterial infection is difficult to define because the 


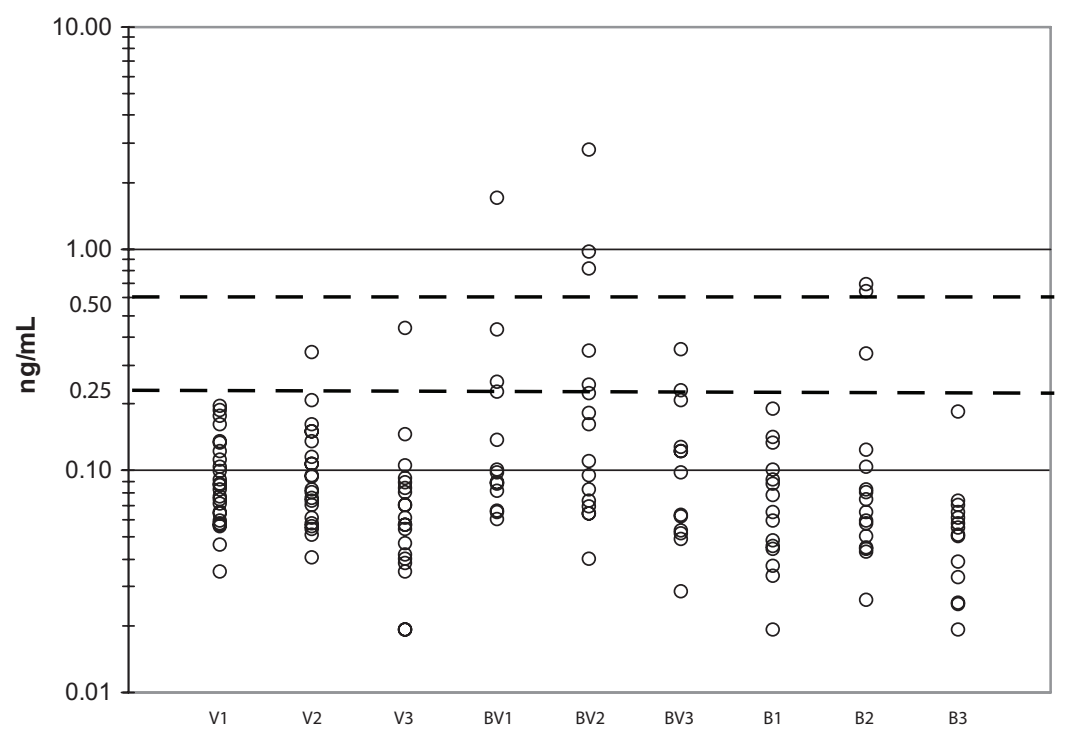

Figure 3 Procalcitonin values in subjects with acute exacerbations of chronic obstructive pulmonary disease without pneumonia. Individual procalcitonin values expressed as $\mathrm{ng} / \mathrm{mL}$ on a log 10 scale. Viral alone patients are shown on admission (VI), day 2 (V2), and day 28 (V3) and bacterial + viral are shown on admission (BVI), day 2 (BV2), and day 28 (BV3) and bacterial alone on admission (BI), day 2 (B2), and day 28 (B3). The $0.25 \mathrm{ng} / \mathrm{mL}$ and $0.50 \mathrm{ng} / \mathrm{mL}$ procalcitonin levels are indicated by the dotted lines.

airways of COPD patients may be chronically colonized. ${ }^{3,4}$ Acquisition of new strains of Haemophilus influenzae and Moraxella catarrhalis, rather than bacterial load, appears to be the most important factor in the pathogenesis of acute exacerbations. ${ }^{35}$ This factor has not been accounted for in AECOPD antibiotic trials and might explain the modest beneficial effects of antimicrobial treatments observed.

We accept that some subjects who were classified as having bacterial infection in our study were colonized rather than infected. However, only $17 \%$ of patients overall with AECOPD and without pneumonia, and only $25 \%$ of those with evidence of bacterial infection had procalcitonin levels $\geq 0.25 \mathrm{ng} / \mathrm{mL}$. While it is possible that this small subgroup represents those who will actually benefit from antibiotic treatment, such a conclusion is premature. Notably, of those with procalcitonin levels $<0.25 \mathrm{ng} / \mathrm{mL}, 57 \%$ had three Anthonisen criteria, suggesting they would benefit from antibiotic treatment based on past studies. ${ }^{36}$ Thus, only two conclusions are possible, ie, either the contribution of bacterial infection in AECOPD has been markedly overestimated or procalcitonin values do not differentiate bacterial bronchitis from viral or noninfectious etiologies.

Our study adds to the growing body of literature which questions the utility of procalcitonin levels to discriminate viral-associated from bacterial-associated AECOPD. In a study by Daniels et al, procalcitonin levels were measured in outpatients enrolled in a trial of doxycycline for AECOPD. ${ }^{37}$ A significant benefit of doxycycline was noted for patients with procalcitonin levels $<0.1 \mathrm{ng} / \mathrm{mL}$. In this study, as well as in two additional reports, no differences in procalcitonin levels were noted in patients with or without bacteria in sputum during exacerbation..$^{32,37,38}$ Our study provides the most rigorous microbiologic analysis of moderate to severe illness requiring hospitalization to date, particularly for subjects who were deemed negative for bacterial infection. Unlike prior studies, we did not consider patients to be free of bacterial infection unless adequate samples were taken in a timely fashion and without antibiotic use prior to hospitalization.

Our study had several limitations. The number of patients with documented bacterial infection was relatively small. However, large numbers of subjects are not needed to show that a test is insensitive, especially if missing even a few patients with potentially treatable bacterial infections is considered unacceptable. Because medical information was restricted to that available in the hospital medical record, we could not classify the stage of COPD using GOLD criteria in our subjects. Lastly, we did not test for rhinovirus, a common pathogen in this population, although this omission does not invalidate the findings for those patients with a viral or bacterial infection identified.

In conclusion, we found that elevated serum procalcitonin levels are associated with more severe illness in patients hospitalized with symptoms of AECOPD and that high values may alert clinicians to the possibility of pneumonia. However, low procalcitonin values do not "rule out" bacterial infection in AECOPD. Before procalcitonin-based treatment algorithms are endorsed, additional studies in COPD patients should be performed. Clinical trials focusing on antibiotic 
benefit are needed specifically in patients with nonpneumonic exacerbations associated with low procalcitonin values.

\section{Acknowledgments}

The authors wish to thank Jamie Biear, Karen Leavenworth, and Kyle Quinn for their technical support, Susan Romansky, Tashara Smalls, and the staff of the Rochester General Hospital clinical microbiology, hematology and chemistry laboratory for assistance with specimen retrieval, and members of the respiratory therapy department for help with sputum induction. This work was supported by the National Institute Health at the National Institute of Allergy and Infectious Diseases (1R01AI079446-01).

\section{Disclosures}

Dr Falsey has served as a consultant for sanofipasteur, GSK Biologics, Medimmune, AstraZeneca, and Novartis. Dr Walsh has served as a consultant for Novartis, Alnylam, AstraZeneca, Medimmune, and Boehringer Ingelheim. Otherwise, the authors have no financial conflicts of interest which could potentially bias the results of the study.

\section{References}

1. Pauwels RA, Buist AS, Calverley PM, Jenkins CR, Hurd SS; GOLD Scientific Committee. Global strategy for the diagnosis, management, and prevention of chronic obstructive pulmonary disease. NHLBI/ WHO global initiative for chronic obstructive lung disease (GOLD) workshop summary. Am J Respir Crit Care Med. 2001;163(5): 1256-1276.

2. Ram FS, Rodriguez-Roisin R, Granados-Navarrete A, Garcia-Aymerich J, Barnes NC. Antibiotics for exacerbations of chronic obstructive pulmonary disease. Cochrane Database Syst Rev. 2006;2:CD004403.

3. Monso E, Ruiz J, Rosell A, et al. Bacterial infection in chronic obstructive pulmonary disease. A study of stable and exacerbated outpatients using the protected specimen brush. Am J Respir Crit Care Med. 1995; 152(4 Pt 1):1316-1320.

4. Martinez FJ. Pathogen-directed therapy in acute exacerbations of chronic obstructive pulmonary disease. Proc Am Thorac Soc. 2007;4(8):647-658.

5. Kherad O, Rutschmann OT. Viral infections as a cause of chronic obstructive pulmonary disease (COPD) exacerbation. Praxis (Bern 1994). 2010;99(4):235-240. German.

6. De Serres G, Lampron N, La Forge J, et al. Importance of viral and bacterial infections in chronic obstructive pulmonary disease exacerbations. J Clin Virol. 2009;46(2):129-133.

7. Fowler CL. Procalcitonin for triage of patients with respiratory tract symptoms: A case study in the trial design process for approval of a new diagnostic test for lower respiratory tract infections. Clin Infect Dis. 2011;52(4):S351.

8. Becker KL, Nylen ES, White JC, Muller B, Snider RH Jr. Clinical review 167: Procalcitonin and the calcitonin gene family of peptides in inflammation, infection, and sepsis: A journey from calcitonin back to its precursors. J Clin Endocrinol Metab. 2004;89(4): $1512-1525$.

9. Muller B, White JC, Nylen ES, Snider RH, Becker KL, Habener JF. Ubiquitous expression of the calcitonin-i gene in multiple tissues in response to sepsis. J Clin Endocrinol Metab. 2001;86(1):396-404.
10. Gendrel D, Raymond J, Coste J, et al. Comparison of procalcitonin with C-reactive protein, interleukin 6 and interferon-alpha for differentiation of bacterial vs viral infections. Pediatr Infect Dis J. 1999;18(10):875-881.

11. Nylen ES, Snider RH Jr, Thompson KA, Rohatgi P, Becker KL. Pneumonitis-associated hyperprocalcitoninemia. Am J Med Sci. 1996;312(1):12-18.

12. Becker KL, Snider R, Nylen ES. Procalcitonin in sepsis and systemic inflammation: A harmful biomarker and a therapeutic target. $\mathrm{Br} J$ Pharmacol. 2010;159(2):253-264.

13. Christ-Crain M, Stolz D, Bingisser R, et al. Procalcitonin guidance of antibiotic therapy in community-acquired pneumonia: A randomized trial. Am J Respir Crit Care Med. 2006;174(1):84-93.

14. Christ-Crain M, Jaccard-Stolz D, Bingisser R, et al. Effect of procalcitonin-guided treatment on antibiotic use and outcome in lower respiratory tract infections: Cluster-randomised, single-blinded intervention trial. Lancet. 2004;363(9409):600-607.

15. Stolz D, Christ-Crain M, Bingisser R, et al. Antibiotic treatment of exacerbations of COPD: A randomized, controlled trial comparing procalcitonin-guidance with standard therapy. Chest. 2007;131(1):9-19.

16. Schuetz P, Christ-Crain M, Thomann R, et al. Effect of procalcitoninbased guidelines vs standard guidelines on antibiotic use in lower respiratory tract infections: The ProHOSP randomized controlled trial. JAMA. 2009;302(10):1059-1066.

17. Kristoffersen KB, Sogaard OS, Wejse C, et al. Antibiotic treatment interruption of suspected lower respiratory tract infections based on a single procalcitonin measurement at hospital admission - a randomized trial. Clin Microbiol Infect. 2009;15(5):481-487.

18. Briel M, Schuetz P, Mueller B, et al. Procalcitonin-guided antibiotic use vs a standard approach for acute respiratory tract infections in primary care. Arch Intern Med. 2008;168(18):2000-2007.

19. Gilbert DN. Procalcitonin as a biomarker in respiratory tract infection. Clin Infect Dis. 2011;52(4):S362.

20. Alscher DM, Mettang T. Procalcitonin in peritoneal dialysis - a useful marker of inflammation? Perit Dial Int. 2005;25(5):441-444.

21. Nahm MH. Bacterial respiratory pathogen reference laboratory. Available from: http://www.vaccine.uab.edu/. Accessed May 11, 2007.

22. Diederen BM, Peeters MF. Rapid diagnosis of pneumococcal pneumonia in adults using the binax NOW streptococcus pneumoniae urinary antigen test. Int J Infect Dis. 2007;11(3):284-285.

23. Maniaci V, Dauber A, Weiss S, Nylen E, Becker KL, Bachur R. Procalcitonin in young febrile infants for the detection of serious bacterial infections. Pediatrics. 2008;122(4):701-710.

24. Nylen E, Muller B, Becker KL, Snider R. The future diagnostic role of procalcitonin levels: The need for improved sensitivity. Clin Infect Dis. 2003;36(6):823-824.

25. Falsey AR, Erdman D, Anderson LJ, Walsh EE. Human metapneumovirus infections in young and elderly adults. J Infect Dis. 2003;187(5): 785-790.

26. Falsey AR, Formica MA, Treanor JJ, Walsh EE. Comparison of quantitative reverse transcription-PCR to viral culture for assessment of respiratory syncytial virus shedding. J Clin Microbiol. 2003;41(9):4160-4165.

27. Gullsby K, Storm M, Bondeson K. Simultaneous detection of Chlamydophila pneumoniae and Mycoplasma pneumoniae by use of molecular beacons in a duplex real-time PCR. J Clin Microbiol. 2008;46(2):727-731.

28. Sethi S, Murphy TF. Infection in the pathogenesis and course of chronic obstructive pulmonary disease. $N$ Engl J Med. 2008;359(22):2355-2365.

29. Schuetz P, Chiappa V, Briel M, Greenwald JL. Procalcitonin algorithms for antibiotic therapy decisions: A systematic review of randomized controlled trials and recommendations for clinical algorithms. Arch Intern Med. 2011;171(15):1322-1331.

30. Martinez FJ, Curtis JL. Procalcitonin-guided antibiotic therapy in COPD exacerbations: closer but not quite there. Chest. 2007;131(1):1-2. 
31. Food and Drug Administration and Infectious Disease Society of America. FDA-IDSA public workshop: Advancing clinical development of molecular and other diagnostic tests for respiratory tract infections, November 12-13, 2009. Available from: http://www.fda. gov/MedicalDevices/NewsEvents/WorkshopsConferences/ucm 181140 . htm. Accessed May 16, 2011.

32. Lacoma A, Prat C, Andreo F, et al. Value of procalcitonin, C-reactive protein, and neopterin in exacerbations of chronic obstructive pulmonary disease. Int J Chron Obstruct Pulmon Dis. 2011;6:157-169.

33. Bafadhel M, Clark TW, Reid C, et al. Procalcitonin and C-reactive protein in hospitalized adult patients with community-acquired pneumonia or exacerbation of asthma or COPD. Chest. 2011;139(6):1410-1418.

34. Murphy TF, Sethi S, Niederman MS. The role of bacteria in exacerbations of COPD. A constructive view. Chest. 2000;118(1):204-209.
35. Sethi S, Evans N, Grant BJB, Murphy TF. New strains of bacteria and exacerbations of chronic obstructive pulmonary disease. $N$ Engl J Med. 2002;347(7):465-471.

36. Anthonisen NR, Manfreda J, Warren CP, Hershfield ES, Harding GK, Nelson NA. Antibiotic therapy in exacerbations of chronic obstructive pulmonary disease. Ann Intern Med. 1987;106(2):196-204.

37. Daniels JM, Schoorl M, Snijders D, et al. Procalcitonin vs C-reactive protein as predictive markers of response to antibiotic therapy in acute exacerbations of COPD. Chest. 2010;138(5):1108-1115.

38. Kherad O, Kaiser L, Bridevaux PO, et al. Upper-respiratory viral infection, biomarkers, and COPD exacerbations. Chest. 2010;138(4): 896-904.

\section{Publish your work in this journal}

The International Journal of COPD is an international, peer-reviewed journal of therapeutics and pharmacology focusing on concise rapid reporting of clinical studies and reviews in COPD. Special focus is given to the pathophysiological processes underlying the disease, intervention programs, patient focused education, and self management protocols.

\section{Dovepress}

This journal is indexed on PubMed Central, MedLine and CAS. The manuscript management system is completely online and includes a very quick and fair peer-review system, which is all easy to use. Visit http://www.dovepress.com/testimonials.php to read real quotes from published authors.

Submit your manuscript here: http://www.dovepress.com/international-journal-of-copd-journal 